\title{
Landscape evolution of Wenchuan earthquake-stricken area in response to future climate change
}

Congrong Li, Ming Wang, Kai Liu, Tom J. Coulthard

\begin{abstract}
The Wenchuan earthquake causes rapid and gradual changes to the local geomorphology in the earthquake stricken areas. Extreme rainfalls can have strong impacts on the local geomorphic evolution and alter the risk of the sub-sequent geohazards and flooding. However, there still lacks of understanding of long-term geomorphic and fluvial evolution in face of changing future climate. In this paper, with spatial (tailoring process) and statistic temporal downscaling methods, we used the NEX-GDDP data to predict future extreme rainfall coupled with the CAESAR-Lisflood model to simulate the landscape evolution in response to climate change. The results show that the geological and geomorphological environment of the basin continues to have a dynamic change after the earthquake and sediment mainly accumulates in the river channels and floodplains, while mountain slopes and gullies show persistent erosion tendency. The extreme rainfalls have greater effects on the areas with more landslides and the topographic change in the landslides zone becomes the dominant control on topographic variation of the basin over time. It still needs nearly 20 years ( 2035) before the geomorphology of the basin becomes stable, and by then the yearly yield keeps at a level of average rate $1^{*} 10^{\wedge} 4 \mathrm{~m}^{3}$. This paper presents a new approach to apply the NEX-GDDP dataset at local scale and conduct future landscape evolution analysis. It explores how the mountainous areas respond and recover under changing future climate post-earthquake, which can provide important information on future geohazards prediction and measures taken.
\end{abstract}

Keywords: CAESAR-Lisflood model, extreme rainfall, climate change, mass movement, NEX-GDDP data 


\section{Introduction}

The Wenchuan earthquake (M 8.0) occurred on May 12, 2008 in Sichuan, China, triggering thousands of geohazards including rock avalanches, landslides, landslide-dammed lakes ("earthquake lakes") and debris flows [1]. Subsequently, the earthquake-stricken areas still experience frequent landslides, debris flows and flash floods [2] that reflect continuing rapid and gradual changes in the geological and geomorphological environment - resulting in ongoing geohazards [3, 4]. Therefore, it is important to understand how the geological and geomorphological environment will continue to evolve post-earthquake in order to predict and mitigate for future geohazards.

By calculating the difference of elevation data (derived from multi-source Digital Elevation Model (DEM) data) in the years following the earthquake, changes in erosion and deposition patterns in the earthquake-stricken area can be analyzed, furthering our understanding of the driving mechanisms of post-earthquake hazards [5, 6]. Dynamic topographic changes in mountainous areas impacted by major earthquakes can have a strong linkage to the development and occurrence of secondary disasters such as new landslides, debris flows and mountain flooding $[5,7,8]$. However, predicting how landscapes affected by earthquakes will respond and recover in the future has received little attention, and this issue is especially important given how future climate change may well alter how the landscapes behave.

One approach to address how earth surface dynamics respond in post-earthquake affected environments is to use numerical modelling. Xie et al. [9] were the first researchers to use the CAESAR-Lisflood model to model landform evolution and sediment migration in a post-earthquake area. Their results showed that the CAESAR-Lisflood model could be used to simulate how landslides interacted with the river channel changing local erosion and deposition patterns as well as predicting basin sediment yields. CAESAR-Lisflood [10] is a landscape evolution model that integrates the Lisflood-FP 2D hydrodynamic model [11] with the CAESAR (Cellular Automaton Evolutionary Slope And River) model [12], which can be used to simulate the landscape evolution subject to fluvial and diffusive erosion and mass movement processes. It contains a distributed version of the hydrological model TOPMODEL [13] enabling it to use rainfall inputs to drive river discharges that then erode and deposit sediment over a range of grainsizes [14-18]. CAESAR-Lisflood can also calculate the mass movement and also allows different distributions of grainsize to be added into the fluvial network representing landslide material [9].

Extreme rainfall has been shown to have strong effects to the evolution of the geological and geomorphological environment [5, 9] and erosion and deposition patterns forecast by the CAESAR-Lisflood model are sensitive to the rainfall information, especially magnitude [19]. Previous applications of CAESAR-Lisflood [20] have used 
synthetic rainfall products driven by downscaled GCM data and more recently using synthetic rainfall derived from local records [21]. There are existing rainfall products available, including the 'NASA Earth Exchange Global Daily Downscaled Projections (NEX-GDDP)' data-set that can provide the future rainfall information. The NEX-GDDP can successfully reproduce the spatial patterns of precipitation extremes over China, and showed higher accuracy results compared with observations than the Global Climate Models (GCMs) [22]. However, at local scale, when compared with the station observations, the uncertainty of the future precipitation data is relatively high with low simulation efficiency $[23,24]$.

In this study, we explore how the geomorphology of drainage basins affected by the Wenchuan earthquake changes under future rainfall predictions. This firstly involves generating future rainfall predictions at local scales for different climate emission scenarios, and then applying these rainfall predictions to the CAESAR-Lisflood model to explore how the post-earthquake landscape evolves.

\section{Study area, data and methods}

\subsection{Study area}

The study area (Fig. 1 (c)) is located at the lower part of the Hongxi River watershed, in the eastern Pingwu county of Sichuan province, China [5, 7]. The area experienced Modified Mercalli Intensity (MMI) scale $X$ and $X I$ shakes during the Wenchuan earthquake on May 12, 2008, that triggered tens of thousands of landslides and produced large volumes of loose material (Yang et al., 2015). For this study the basin was divided into two parts (upstream zone and downstream zone) to match outputs of the Regional Climate Model (RCM) data with a spatial resolution $0.25^{\circ}$ (Fig. $1(a, b)$ ). Nearly $75 \%$ of the total landslides area (2013) were distributed in the downstream area, with the biggest landslide (Maanshi landslide) located in the upstream area [25]. Since the geomorphology of the area outlined in black in Fig. 1 was heavily affected by the earthquake and most of the buildings are located here, the small basin is the area we are mainly focused on, and the results section only shows the landscape evolution characteristics of this small basin. The annual average precipitation is about $700 \mathrm{~mm}$ and nearly $70 \%$ of the rainfall occurs from May to September [26]. Over the past eleven years following the earthquake, the area has experienced persistent landslides, debris flows and flash floods triggered by high rainfall. 

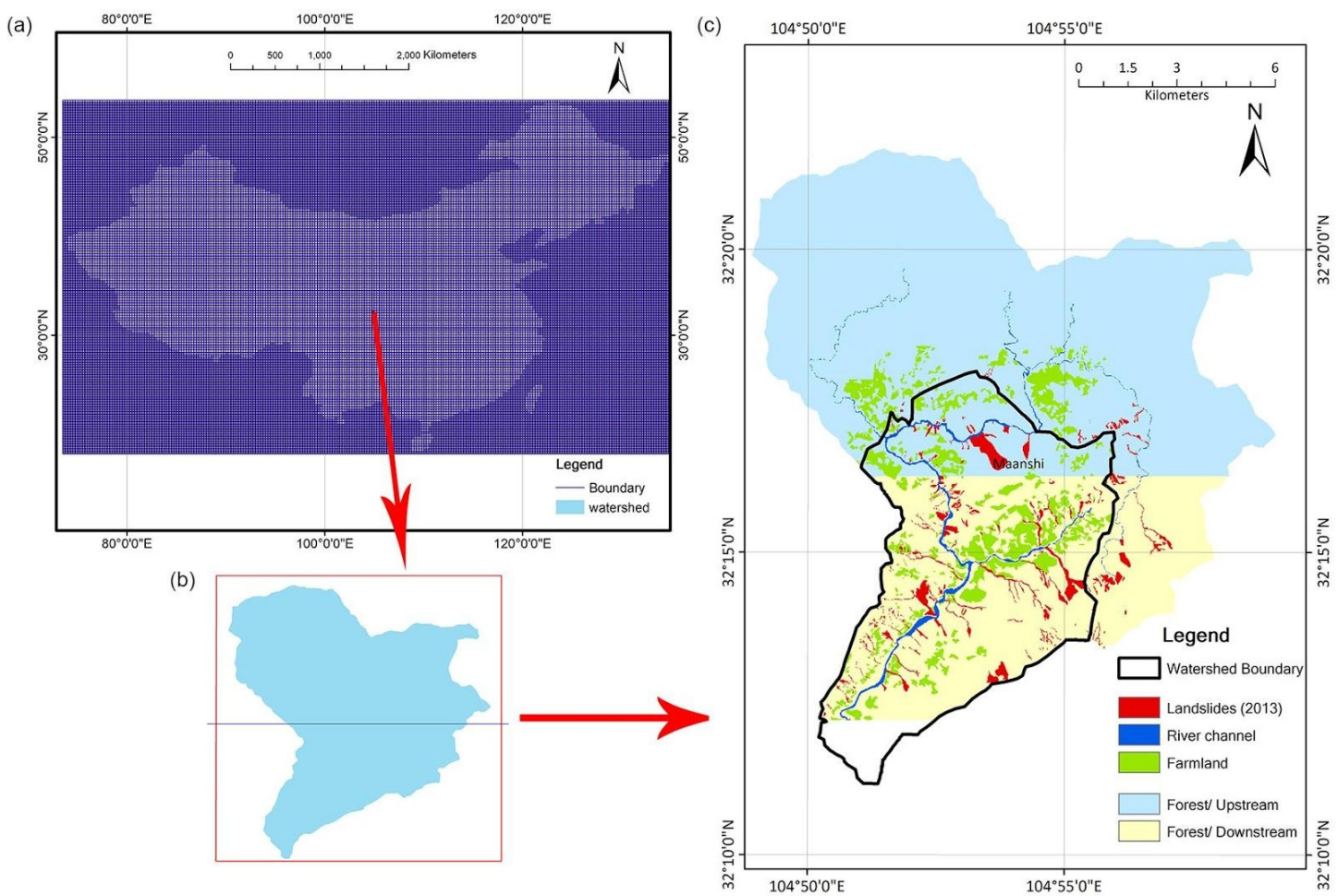

Fig. 1 Spatial boundary of the NEX-GDDP data $\left(0.25^{\circ}\right)$ over China (a); the whole basin was divided into two parts named upstream area and downstream area in this study (b); Land-use information of the basin (Highlighted in black is the lower basin area (c).

\subsection{Data and pre-processing}

The datasets used are summarized in Table 1 and include the high spatial resolution remote sensing images from 2013, the DEM from 2010, daily precipitation records, daily rain gauge data and the NEX-GDDP dataset (RCMs).

Table 1 Datasets used in this research

\begin{tabular}{|c|c|c|c|c|}
\hline \multicolumn{2}{|c|}{ Dataset } & Time & Spatial resolution & Data source \\
\hline NEX-GDDP & Historical run & $1950-2005$ & & \\
\hline dataset (Daily & RCP4.5 runs & $2006-2100$ & $0.25^{\circ}$ & GDDP-NEX \\
\hline Precipitation) & RCP8.5 runs & $2006-2100$ & & \\
\hline \multicolumn{2}{|c|}{$\begin{array}{c}\text { High spatial resolution remote } \\
\text { sensing image }\end{array}$} & 2013 & $4 \mathrm{~m}$ & IKONOS \\
\hline \multirow{2}{*}{\multicolumn{2}{|c|}{ DEM }} & 2010 & 10 m (horizontal) & GlobalDEM \\
\hline & & & & Pingwu \\
\hline \multirow{2}{*}{\multicolumn{2}{|c|}{ Meteorological station data (Daily) }} & $1951-2008$ & & meteorologica \\
\hline & & & & I station \\
\hline \multicolumn{2}{|c|}{ Rain gauge data (Hourly) } & $2015-2018$ & & Hongxi river \\
\hline
\end{tabular}

NEX-GDDP high-resolution daily downscaled data was used to provide the future climate information of the study area and in this study only precipitation data were used. 
The bias-correction spatial disaggregation (BCSD) method was used to generate the NEX-GDDP data-set on the basis of 21 CMIP5 model simulations [27]. The global spatial resolution of the dataset is 0.25 degrees $(\sim 25 \mathrm{~km} \times 25 \mathrm{~km})$. The precipitation data resolution was daily for the period 1950-2005 (historical run) and 2006-2100 (RCP4.5 and RCP8.5 runs). More information can be found at:

\section{https://nex.nasa.gov/nex/projects/1356/.}

The high spatial resolution remote sensing images were used to build the land-use classification results with Fig. 1 showing how the land-use information of the basin was categorized with four different types: landslides, farmland, river-channel and the others (mainly forests).

\subsection{Methods}

The goal of this research is to detect the response of the basin to the future climate change, such as the erosion and deposition patterns after high rainfall events as well as considering the low (RCP4.5) and high (RCP8.5) emission scenario effects for the next $10 \mathrm{y}, 20 \mathrm{y}$ and $50 \mathrm{y}$. Before the Caesar-Lisflood model simulation process (based on the DEM in 2010), the spin up process is needed, in this paper, the time length of the spin up process was settled 3-year under the field-measured rainfall scenario, then the start time to analyze the response to future climate change is 2013. Fig. 2 details a flowchart of the methods used in this research: Future rainfall prediction and the basin response to this rainfall that consists of two main parts.

For the first component, Table 2 showed the temporal line information in the future extreme rainfall prediction process. Such as, in order to get the extreme rainfall in 2006-2025 (next decade after 2013), the history dataset with time line 1986-2005 of the station record and the NEX-GDDP historical runs, together with the future dataset with time line 2006-2025 of the NEX-GDDP future runs were used in the prediction model showed in section 2.3.1. And for each scenario, 50 repeat data sets were generated.

For the second part simulations using the Landscape Evolution Model (LEM) Caesar-Lisflood model were used to examine the basin response to the future climate change reflected in changes in rainfall in part one. For this process, 300 model runs were conducted with different future temporal-scales and different emission scenarios (Table 2). These two parts are described more in the following sections.

Table 2 Temporal-scale information in the station future extreme rainfall prediction process

\begin{tabular}{|c|c|c|c|c|c|}
\hline $\begin{array}{l}\text { Caesar-Lisflood model } \\
\text { input rainfall information }\end{array}$ & \multicolumn{3}{|c|}{ Input value temporal-scale } & \multicolumn{2}{|c|}{$\begin{array}{c}\text { Predicted station future } \\
\text { rainfall }\end{array}$} \\
\hline Temporal-sc Emission & Station & NEX- & & tempora & Number of \\
\hline scenario & record & Historical & Future & I-scale & random tests \\
\hline
\end{tabular}




\begin{tabular}{|c|c|c|c|c|}
\hline & & runs & runs & \\
\hline $2013-2025$ & RCP4.5 & \multirow{2}{*}{$1986-2005$} & \multirow{2}{*}{ 2006-2025 } & 50 \\
\hline (10y) & RCP8.5 & & & 50 \\
\hline 2013-2035 & RCP4.5 & \multirow{2}{*}{$1976-2005$} & \multirow{2}{*}{ 2006-2035 } & 50 \\
\hline (20y) & RCP8.5 & & & 50 \\
\hline 2013-2065 & RCP4.5 & \multirow{2}{*}{$1951-2005$} & \multirow{2}{*}{ 2006-2065 } & 50 \\
\hline$(50 y)$ & RCP8.5 & & & 50 \\
\hline
\end{tabular}

Future rainfall prediction

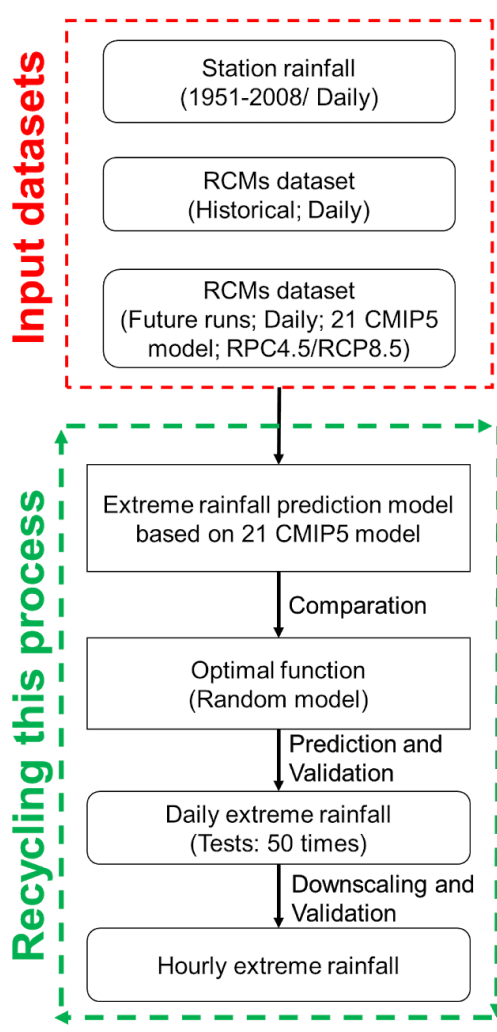

Basin response to the future climate change

Basin response to the future climate change

Comparation

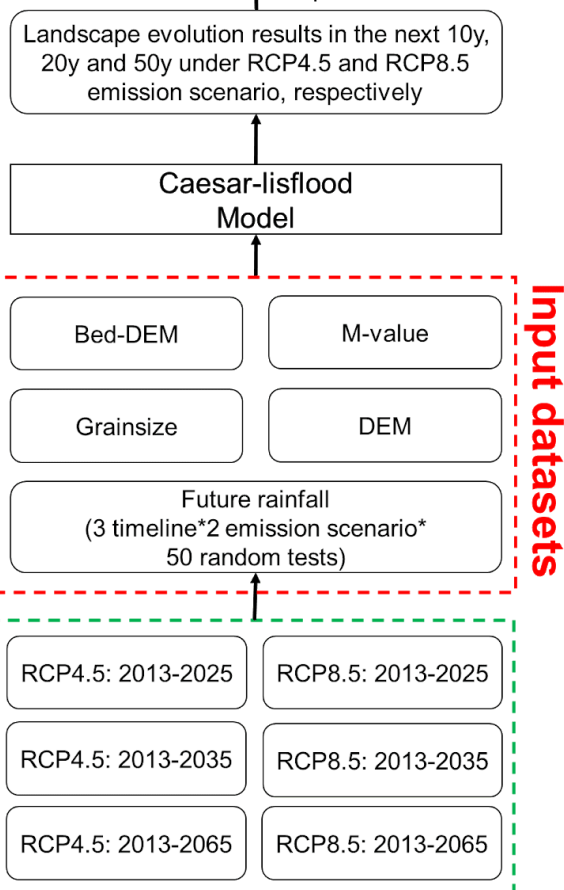

Fig. 2 Flow chart describing the generation of future rainfall and its input into the

\section{CAESAR-Lisflood model}

\subsubsection{Extreme rainfall prediction and downscaling process}

As large rainfall events can have great effects on the landscape evolution process it is important that they are captured within simulated rainfall [5, 28-33]. Using the daily precipitation data of the Pingwu station and assuming that the extreme rainfall obeys the Generalized Extreme Value (GEV) distribution, the station extreme rainfall return period results are shown in Fig. 3. However, when calculating the number of the extreme rainfall (5-year return period events: $97 \mathrm{~mm} /$ day (Fig. 3)) of the 21 CMIP5 models in NEX-GDDP dataset, the NEX-GDDP data shows lower predictions of extreme rainfall compared to the station record and therefore cannot be applied. 


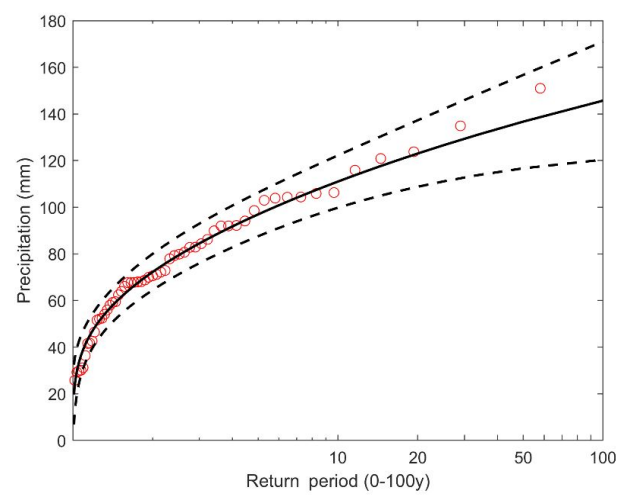

Fig. 3 Return period of the extreme rainfall based on Pingwu station record (1952-2008)

To rectify this, using methods of [34] the distribution statistical results $\left(D_{k}\right)$ of the extreme rainfall predicted model can be calculated with formula (1), the optimal $D_{k}$ of the station future data occurs when the difference between the relationship between RCMfuture and RCMhistorical and Stationfuture and Stationhistorical of the 21 CMIP5 model is the smallest. Then the future station precipitation data can be predicted using this optimal random extreme distribution model.

$$
D_{k}=\left(\frac{M_{g}}{M_{\text {obs }}}-\frac{M_{R C \text { Mfuture }}}{M_{R C M \text { historical }}}\right)^{2}+\left(\frac{C V_{g}}{C V_{\text {obs }}}-\frac{C V_{R C M \text { future }}}{C V_{R C M \text { present }}}\right)^{2}+\left(\frac{S_{g}}{S_{\text {obs }}}-\frac{S_{R C M \text { future }}}{S_{R C M \text { present }}}\right)^{2}+\left(\frac{\rho_{1 g}}{\rho_{\text {lobs }}}-\frac{\rho_{1 R C M \text { future }}}{\rho_{1 R C M \text { present }}}\right)^{2}
$$

Where $M$ refers to Mean value, $C V$ refers to the coefficient of variability, $S$ is skewness, $\rho_{1}$ is the first order autocorrelation coefficient of the daily precipitation time series data, $g$ refers to the future time series data and obs is the station observation data. The index parameters, such as $M, C V, S$ and $\rho$ in equation (1) can be replaced by other index parameters. In this study, the index parameters included: mean value, coefficient of variability, skewness, kurtosis, $80 \%$ quantile, $90 \%$ quantile, $95 \%$ quantile and $99 \%$ quantile of station history data, NEX-GDDP historical runs data and future runs data. Three time-lines (2006-2025, 2006-2035 and 2006-2065) were simulated and four typical extreme distribution model (Gamma, Extreme value, Generalized Extreme value, and Generalized Pareto distribution) were selected to simulate the future optimal distribution function of the extreme rainfall.

To best capture hydrological events in catchments of this size using CAESAR-Lisflood the temporal resolution of the rainfall needs to be sub daily - ideally hourly. Since the temporal resolution of the station data and the NEX-GDDP data is daily, in this research, a stochastic temporal downscaling model based on a genetic algorithm (GA) [35] was used to temporally downscale the daily time series to hourly time series. To carry out this downscaling we divided the daily rainfall into 4 levels: $>100 \mathrm{~mm}$; $50-100 \mathrm{~mm} ; 20-50 \mathrm{~mm}$ and $0-20 \mathrm{~mm}$ and conducted the downscaling process individually. The first step is to estimate the distances between the target daily precipitation $Y_{t}$ and the 
observed daily precipitation $y_{i}=\sum_{h=1}^{24} x_{i, h}, \mathrm{i}=1,2, \ldots \ldots \mathrm{n}, x_{i, h}$ is the hourly observations

$$
D_{i}=\left(Y_{t}-y_{i}\right)^{2}
$$

where $t=1,2, \ldots \ldots T, T$ is the length of the target daily precipitation, $n$ is the record length and $h$ indicates the $h$ th hour.

Then the results from equation 2 were arranged in ascending order, provided the number of nearest neighbors, $k$, a known value (in this research, $\mathrm{k}=\mathrm{sqrt}(\mathrm{num})$, where num is the number of the hourly observation in each rainfall level), and selected the smallest $k$ values and reserve the time indices. Then one of the $k$ time indices was randomly selected with a weighting probability as per equation 3 :

$$
w_{m}=\frac{1 / m}{\sum_{j=1}^{k} 1 / j}, m=1, \ldots \ldots . k \text {. }
$$

Here it is assumed that the selected time indices is $p$, then the selected time index is $X_{p}=\left[x_{p, h}\right] h \in\{1,24\} \cdot$

Then the GA mixing process was used, with the reproduction, crossover and mutation method, then repeat tested until the required data were generated. The adjusted process to make everyday rainfall equal the target precipitation and the gradual variation in precipitation events are also considered in this downscaling process.

The GA mixing process followed:

Reproduction: select another time index $p^{*}$, and obtain the corresponding hourly Precipitation: $X_{p^{*}}=\left[x_{p^{*}, h}\right] h \in\{1,24\}$

Crossover: replace element $x_{p, h}$ with $x_{p^{*}, h}$ when $\varepsilon<P_{c}$, where $\varepsilon$ is a uniformly distributed random number between 0 and 1 . In this research, $P_{c}$ equals to 0.1 .

Mutation: replace element $x_{p, h}$ with $x_{\xi, h}$, where $x_{\xi, h}$ is selected from $\left[x_{i, h}\right] i \in\{1, n\}$ with equal probability for $\mathrm{i}=1, \ldots \ldots, \mathrm{n}$ when $\varepsilon<P_{m}$. In this research, $P_{c}$ equals to 0.01 .

\subsubsection{Caesar-Lisflood model}

CAESAR-Lisflood model [10] is a raster-based landscape evolution model with four main modules: hydrological module that calculates streamflow from rainfall rates using a spatially distributed version of TOPMODEL, a hydrodynamic flow routing module based on the Lisflood-FP method [11], erosion and deposition over 9 different grainsizes as well as lateral erosion, and a slope processes module simulating landslides and soil creep. In the model simulation process, the basin is divided into a mesh of grid cells, each cell contains its elevation, grainsize, and hydrological parameters (e.g., discharge, water depth, etc.) and these cell values are updated according to process based rules for erosion/deposition, hydrology and slope processes. 
As the run time of CAESAR-Lisflood simulations increases with the number of grid cells (translating directly into the number of calculations), in this study, we resampled the spatial resolution of all the input data to $20 \mathrm{~m}$. These input parameters include elevation, grainsize, bed rock DEM (BedDEM), M-value, landuse and rainfall (as shown in Fig. 2). Output data recorded included the changed DEM, waterdepth, daily sediment, discharge, and grainsize information. More information on the model parameters can be found on the model website: https://sourceforge.net/p/caesar-lisflood/wiki/lnstructions/. The BedDEM was built based on the surface DEM minus $3 \mathrm{~m}$. Grainsize information are derived from field surveys. Different land use areas were modeled by altering M-value in the hydrological model which controls the peak and duration of a flood hydrograph for a given storm event [12]. Different land-use type refers to different M-value. In this study the M-value for forest, farmland, landslide and river channel were set as $0.02,0.008$, 0.003 and 0.002 , respectively as per[9].

\section{Results}

\subsection{Predicted extreme rainfall distributions}

Fig. 4 and Table 3 show the optimal prediction distribution function of station future extreme rainfall (top 20 each year), varying with the different temporal scale and emission scenarios as well as the difference of the upstream and downstream area. This distribution function is then used to predict the station future extreme rainfall. Since the rainfall generation is stochastic 50 repeat data sets were generated in each temporal period (2013-2025; 2013-2035; 2013-2065) and emission scenarios (RCP4.5 and RCP8.5) (Table 2).
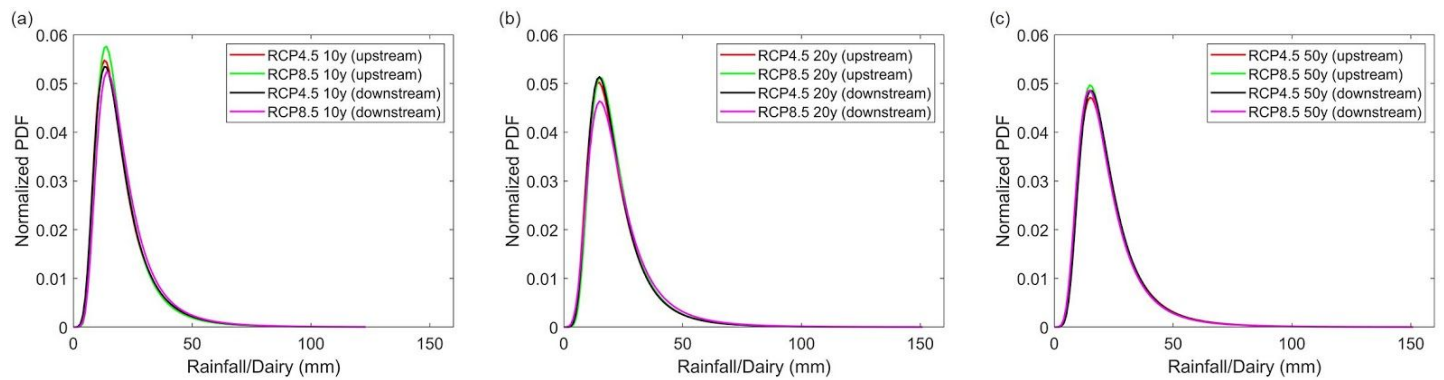

Fig. 4 Future extreme rainfall prediction distribution function in 2013-2025 (a); 2013-2035 (b) and 2013-2065 (c).

Table $3 D_{k}$ information of the Future extreme rainfall prediction distribution function in 2013-2025 (10y); 2013-2035 (20y) and 2013-2065 (50y)

\begin{tabular}{|c|c|c|c|c|c|c|c|c|c|c|c|c|}
\hline \multirow{3}{*}{ Time } & \multicolumn{6}{|c|}{ RCP4.5 } & \multicolumn{6}{|c|}{ RCP8.5 } \\
\hline & \multicolumn{3}{|c|}{ upstream } & \multicolumn{3}{|c|}{ downstream } & \multicolumn{3}{|c|}{ upstream } & \multicolumn{3}{|c|}{ downstream } \\
\hline & $\mathrm{k}$ & $\sigma$ & $\mu$ & $\mathrm{k}$ & $\sigma$ & $\mu$ & $\mathrm{k}$ & $\sigma$ & $\mu$ & $\mathrm{k}$ & $\sigma$ & $\mu$ \\
\hline $\begin{array}{c}10 \\
\text { year }\end{array}$ & 0.22 & 6.87 & $\begin{array}{c}14.5 \\
6\end{array}$ & 0.21 & 7.01 & $\begin{array}{c}14.7 \\
2\end{array}$ & 0.21 & 6.50 & $\begin{array}{c}14.8 \\
7\end{array}$ & 0.21 & 7.16 & $\begin{array}{c}15.6 \\
4\end{array}$ \\
\hline $\begin{array}{c}20 \\
\text { year }\end{array}$ & 0.20 & 7.45 & $\begin{array}{c}15.9 \\
8\end{array}$ & 0.20 & 7.30 & $\begin{array}{c}16.1 \\
5\end{array}$ & 0.20 & 7.30 & $\begin{array}{c}16.6 \\
4\end{array}$ & 0.20 & 8.08 & $\begin{array}{c}16.6 \\
4\end{array}$ \\
\hline $\begin{array}{l}50 \\
\text { year }\end{array}$ & 0.20 & 7.95 & $\begin{array}{c}16.6 \\
5\end{array}$ & 0.20 & 7.71 & $\begin{array}{c}16.8 \\
2\end{array}$ & 0.20 & 7.54 & $\begin{array}{c}16.4 \\
9\end{array}$ & 0.20 & 7.71 & $\begin{array}{c}16.1 \\
5\end{array}$ \\
\hline
\end{tabular}


${ }^{*} \mathrm{k}$ is shape parameter, $\sigma$ is the scale parameter and $\mu$ is the location parameter. All the functions obey the GEV model.

For the predicted future extreme rainfall, more extreme rainfall events (10-year return period events) occurred under the RCP4.5 emission scenario, especially in the upstream area (Fig. 5). We also calculated the frequency of the daily rainfall exceeded $20 \mathrm{~mm}$ for more than three consecutive days (Fig. 6) and the result also showed that more extreme rainfall occurred under the RCP4.5 emission scenario of our basin.
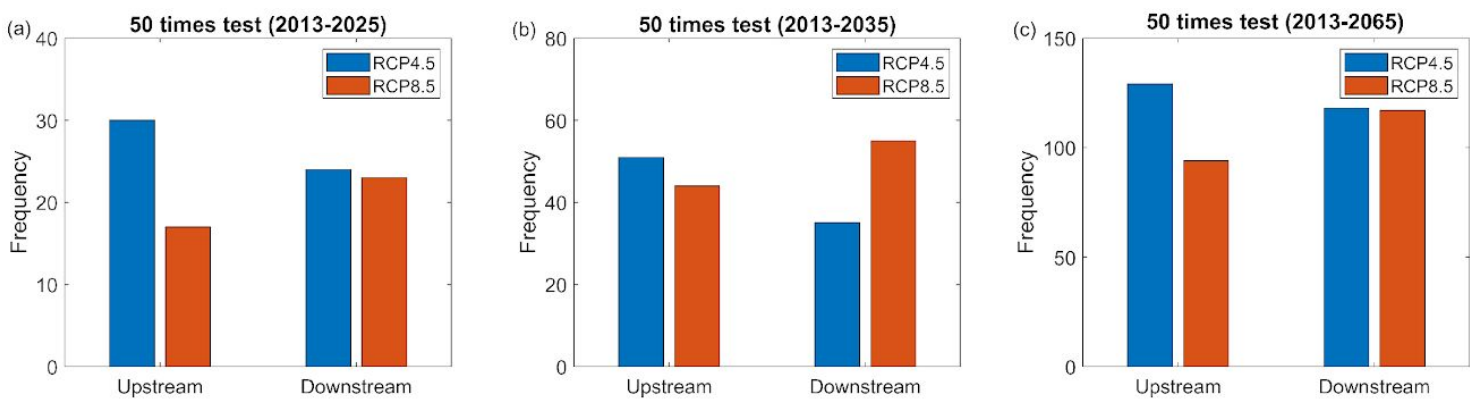

Fig. 5 The frequency of the extreme rainfall with return period higher than 10y in all 50 tests ((a), (b) and (c) are the results in 2013-2025, 2013-2035, and 2013-2065, respectively.)
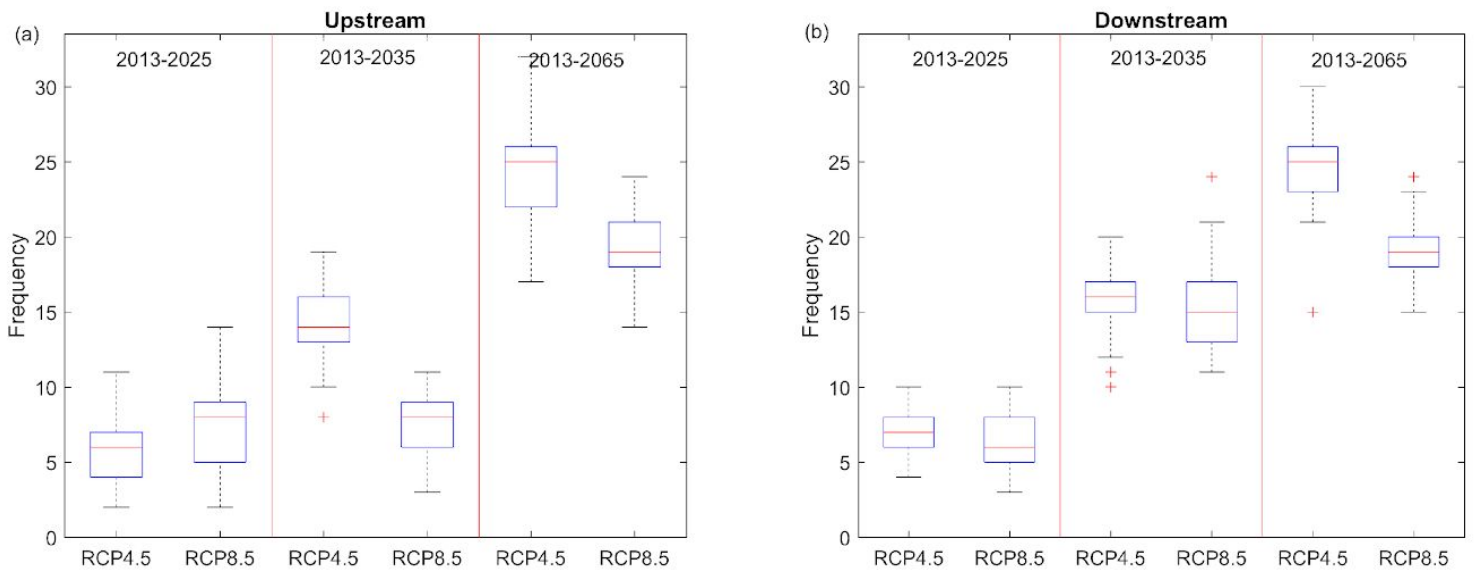

Fig. 6 The frequency of the daily rainfall exceeding $20 \mathrm{~mm}$ for more than three consecutive days in the upstream (a) and downstream (b) area

\subsection{Sediment variation characteristics in different temporal scale}

We calculated the relationship (Table 3 ) between the total volume of the sediment and the cumulative rainfall and the relationship between the maximum sediment each year and the maximum rainfall of that day or the day before it. All the results showed high $\mathrm{R}$-value between the sediment and the upstream rainfall information. The results indicate that in our study area, the upstream rainfall is the dominant control on the sediment yield of the basin. 
Table 3 The relationship (R: correlation coefficient) between the sediment and the rainfall

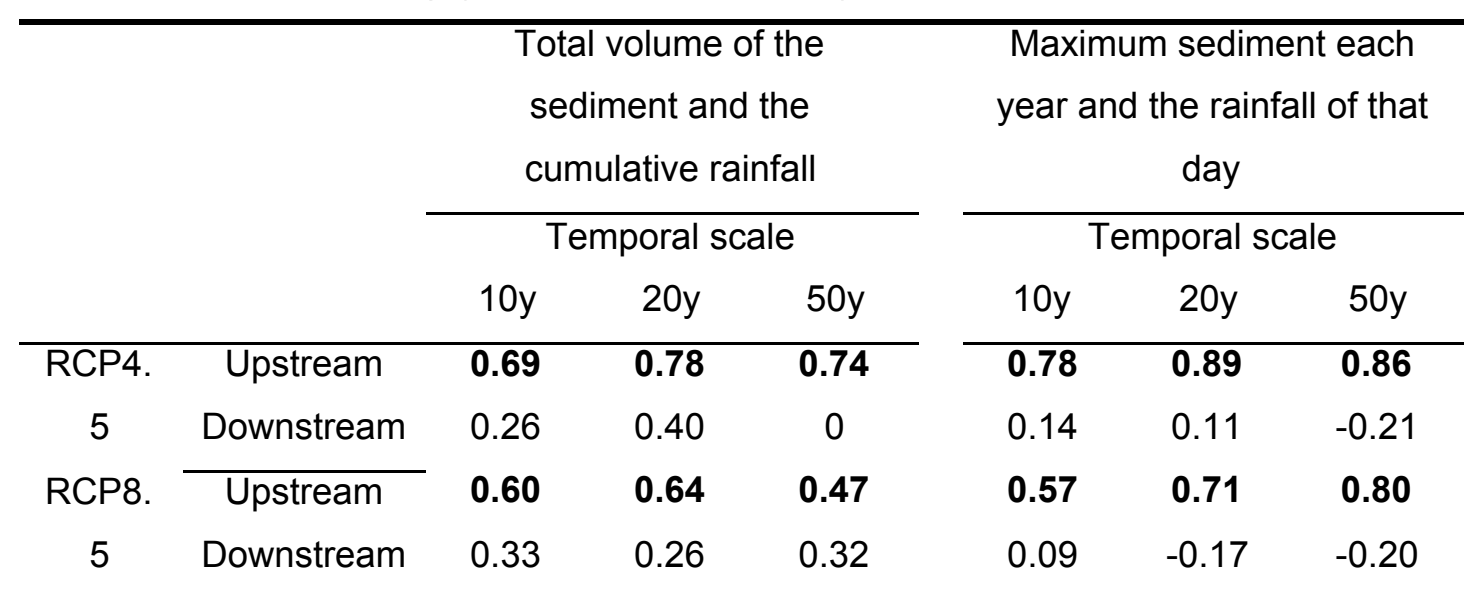

Fig. 7 presents time series of the sediment yields as well as the cumulative sediment yield from the 50 tests for each scenario. The erosion intensity is stronger under the RCP4.5 emission scenario and there is a clear relationship between the extreme rainfall events and spikes in sediment yield, although the steady rise of the cumulative curve shows the contribution of smaller events too.
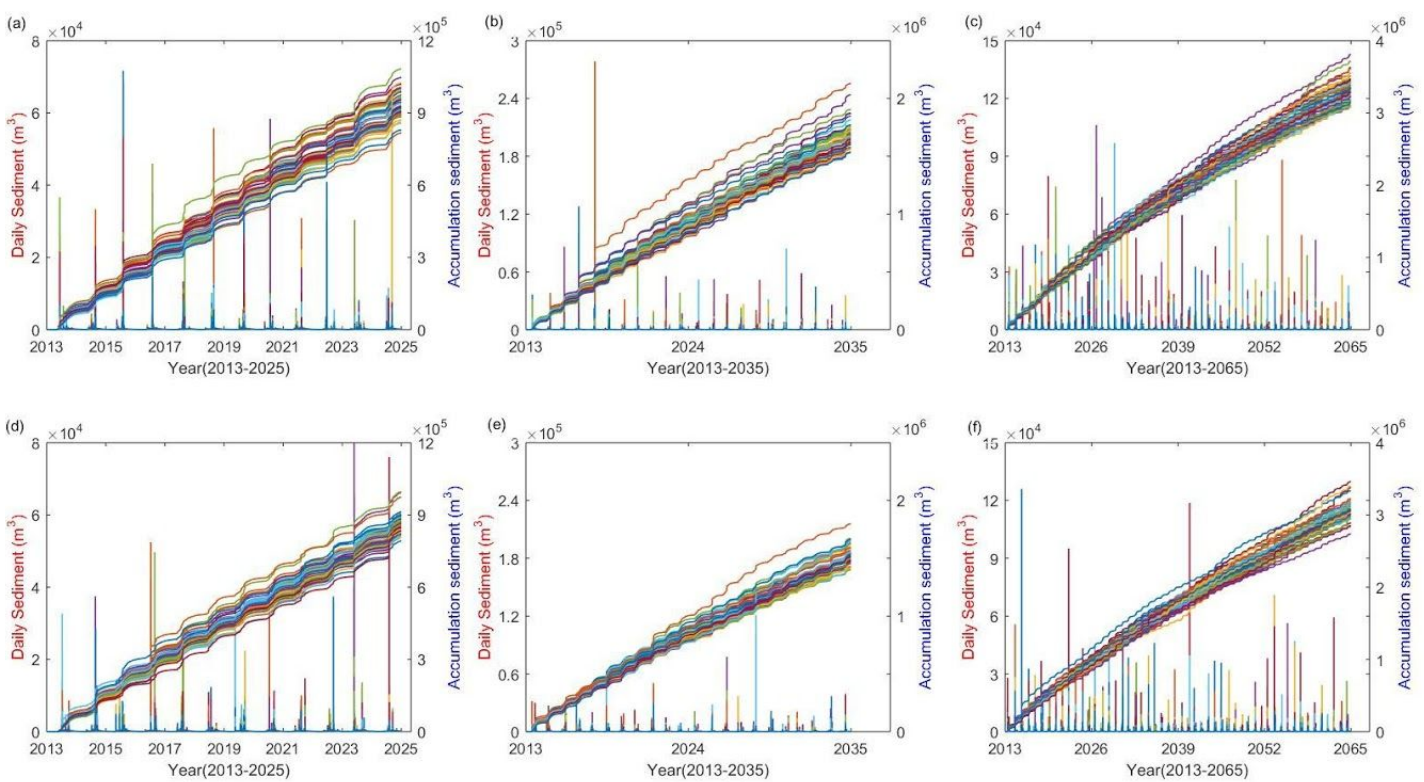

Fig. 7 Time series and cumulative sediment of the 50 tests in the $10 y(a, d), 20 y(b, e)$ and $50 y(c, f)$ landscape evolution process $(a, b$, and $c$ are the results under the RCP4.5 emission scenario and $d, e$, and $f$ are the results under the RCP8.5 emission scenario). (Different colored lines represent different tests. Note different $Y$ axis scaling). 

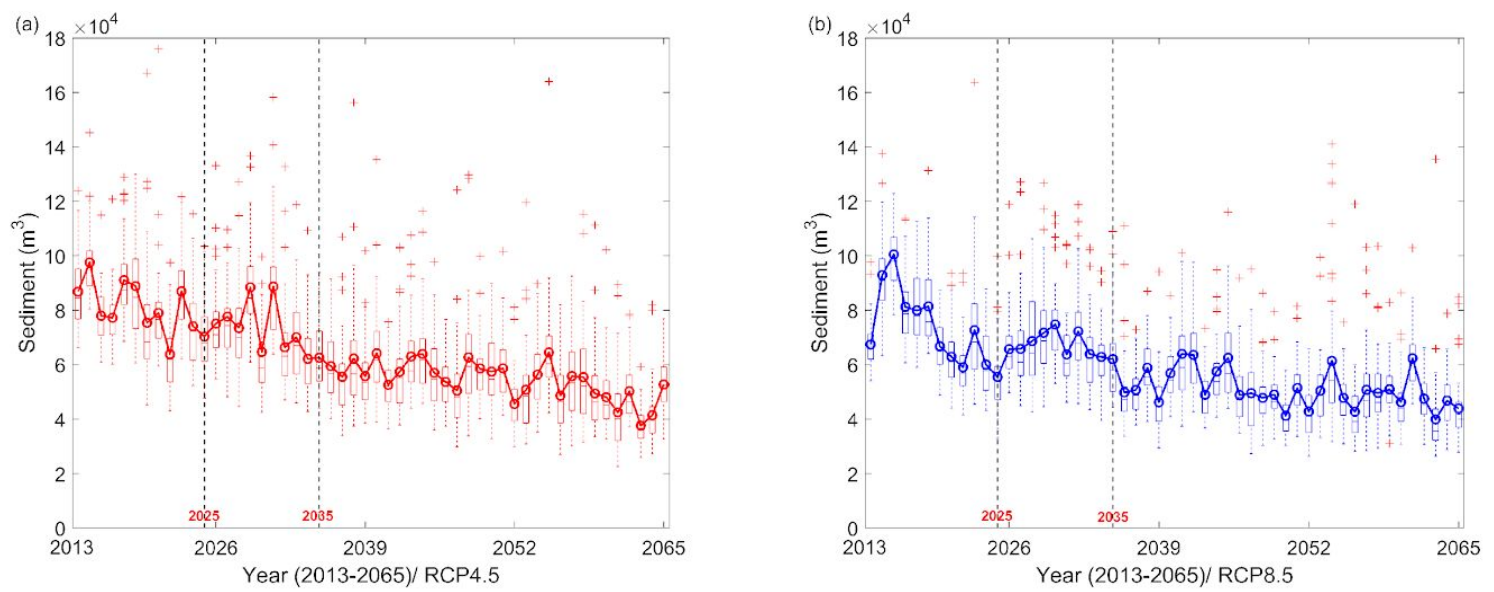

Fig. 8 Box and whisker plots of annual mean sediment yields (for all 50 simulations) from 2013-2065 with the RCP4.5 and RCP8.5 scenarios.

Fig. 8 shows the mean annual sediment yields from the simulations showing a decrease during the period 2013-2065 under the RCP4.5 and RCP8.5 emission scenarios, with fluctuations due to the nonlinear behavior of the basin geomorphology.

\subsection{Topographic variation after the earthquake}

\subsubsection{Mean elevation change}

Fig. 9 shows the mean elevation changes of the 50 simulations in the next 50 years based by averaging changes for each pixel from the 50 simulations. Overall there are clear patterns of aggradation and sediment accumulation in the river channels and floodplains and erosion on mountain slopes and gullies.

(a)

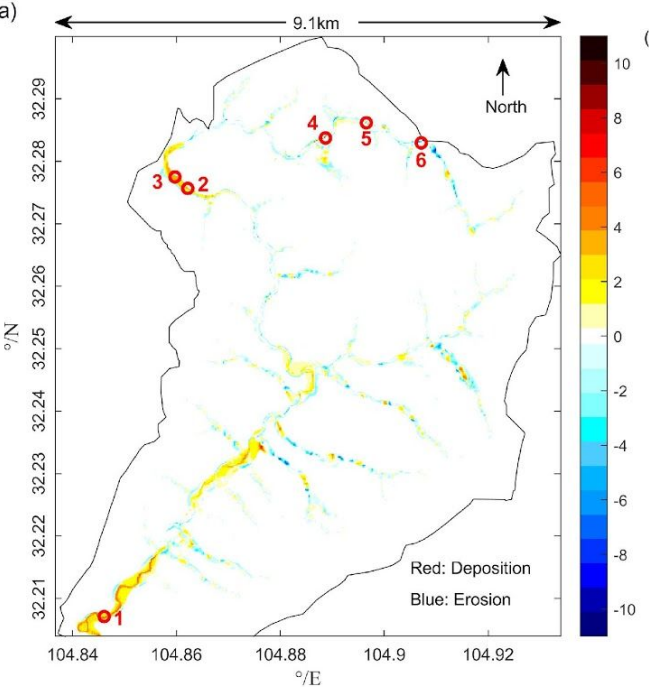

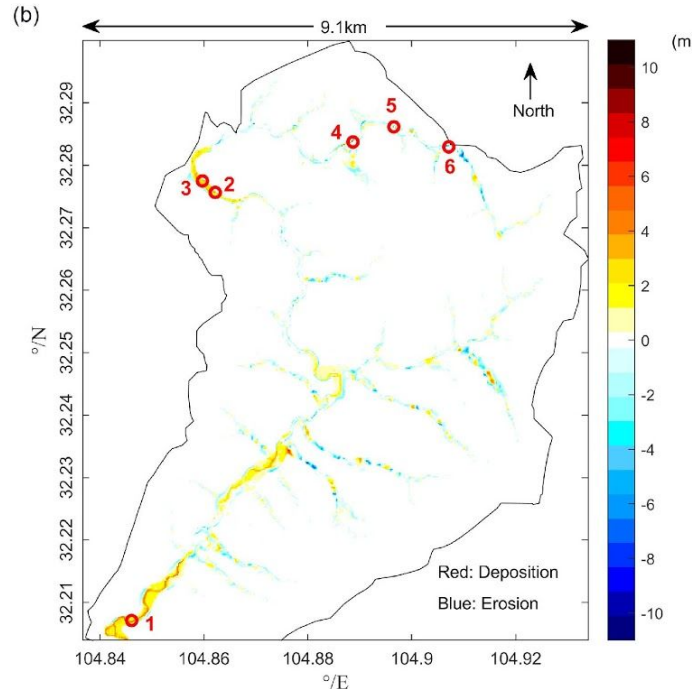

Fig. 9 Mean elevation change in the next 50 years after 2013 under the RCP4.5 (a) and RCP8.5 (b) emission scenario 
As simulations progress sediment is moved downstream towards the the outlet as illustrated in the channel profile change charts of Fig. 10 where the closer to the outlet, the bigger increase the elevation change over time.

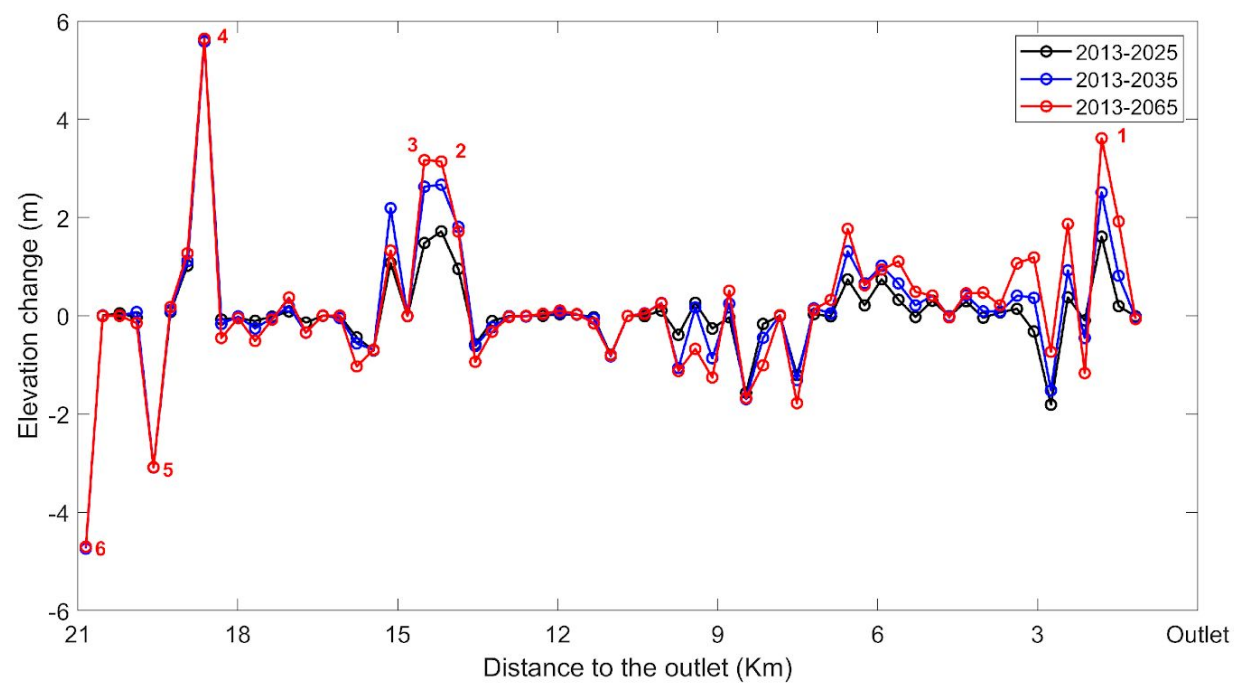

Fig. 10 Elevation change along the channel from top to the outlet (Maanshi direction; the number 1-6 refers to the points with elevation change (erosion and deposition) higher than $3 m$, also showed in Fig. 9)
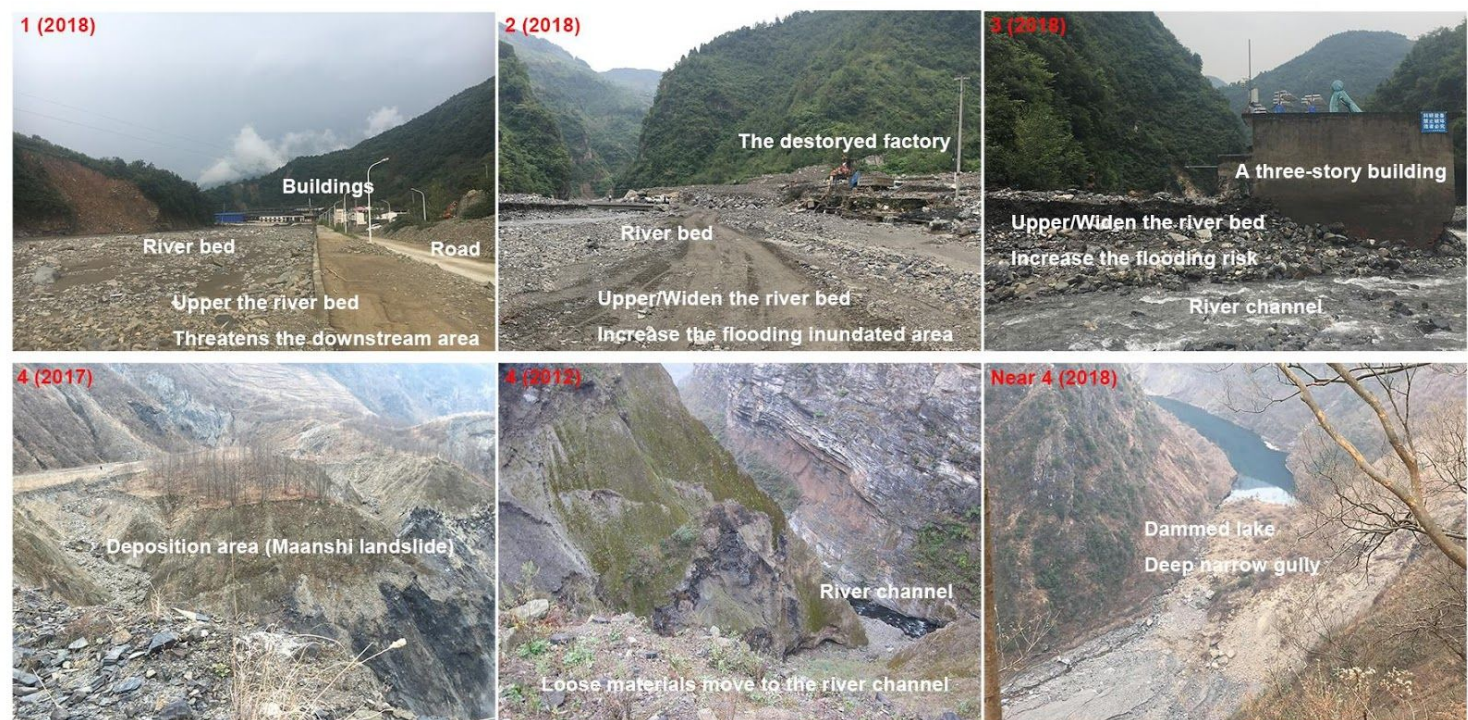

Fig. 11 Photos taken at in points 1-4 in Figures 9 and 10 (the geomorphology environment of point 5 and 6 are very like point 4 , while without too many landslides)

Points 1-4 identified in Figures 9 and 10 show locations where deposition is greater than $3 \mathrm{~m}$ by 2065 and pictures of these locations are provided in Fig. 11. The simulated elevation changes during the period 2013-2025 at point 1, 2, 3 and 4 are consistent with our observations in 2018. Point 1 refers to the area very near the outlet, under the river transportation process, loose materials move to the outlet, raising the river bed and in Fig. 11 (the photo taken in 2018) the river bed is now full of loose material with a higher 
elevation than the road, posing a threat to the villages downstream. Point 2 and 3 are all located downstream of Maanshi landslide (point 4), with very wide and flat river bed. The photos taken in 2018 show that the deposition materials widen and raise the river bed increasing the flooding intensity and the inundated area. The factory built in 2017 were destroyed by the 2018 flooding (point 2), and only one and a half stories left in a three-story building (point3). Point 4 is located just below the main body of Maanshi landslide, where rainfall has caused a large volume of landslide material to move to the river channel which again aggrades/raises the river bed. The mountains located in the upstream (point 5 and 6 ) and downstream (not very far) of Maanshi landslides are all with high cliffs and deep gullies, which forms a steep and narrow V-like channel. Here, the vertical incision of the river is stronger than its lateral erosion, and lateral erosion can trigger local landslides to dam the river threatening downstream.

\subsubsection{Mass balance of the lower basin area after 2013}

Focusing on the lower basin area outlined in Fig. 1, we compared the mass change after 2013 in the next 50 years with 35 tests under the RCP4.5 emission scenario. Here positive values in Fig. 12 reflect the net addition of sediment to this area from upstream sources and negative values an overall loss. Fig. 12(a) showed the comparison results between the whole basin material volume and the material volume in 2013 year after year, the results showed that the whole basin material volume will be lesser than that in 2013 after 2035, and the whole basin material volume change tendency varied from deposition to erosion. Fig. 12(b) showed the material volume change compared with the material volume between the consecutive two years, the sediment yield rate tends to be stable after nearly 20 years, with the yearly average sediment yield rate nearly equals to $1 * 10^{4} \mathrm{~m}^{3}$.
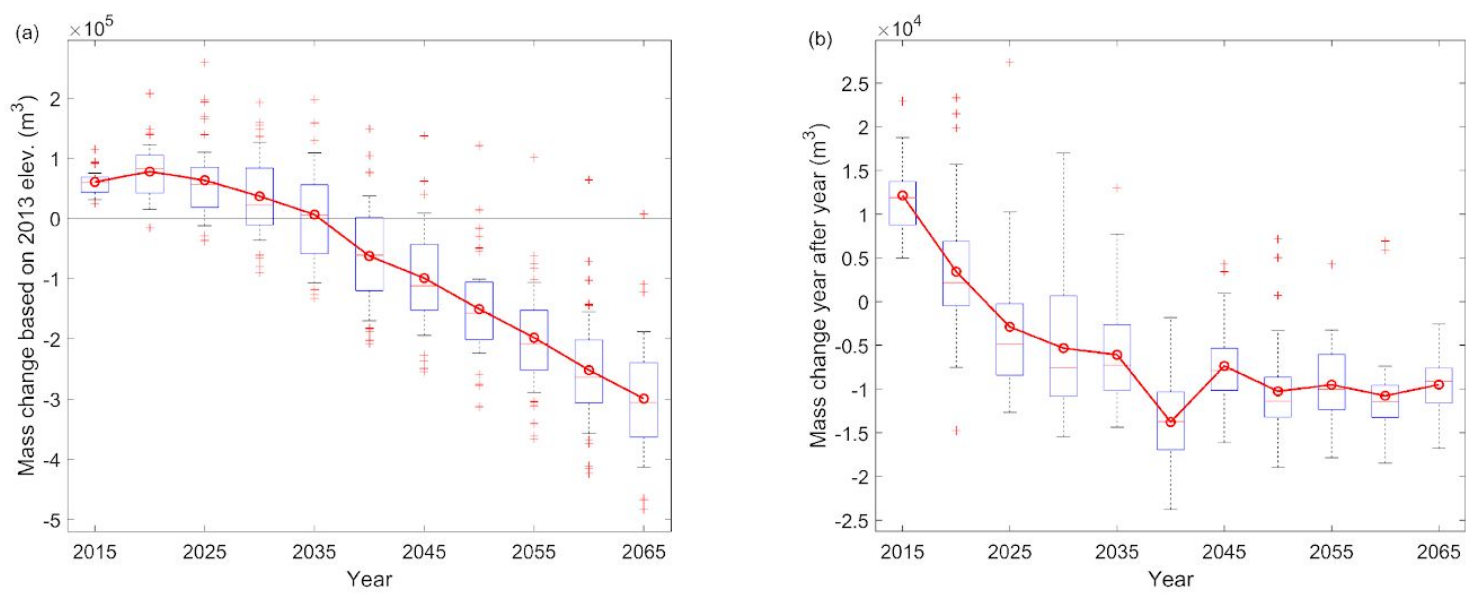

Fig. 12 Whole basin mass volume change (baseline: material volume in 2013) (a) and mass volume change year-after-year (b) 5 yearly changes in mass balance 
Over time, the ratio of volume change between the landslides zone (Lower basin, Fig. 1) and the non-landslides zone (upper basin, Fig. 1) became larger (Fig. 13), which indicates that over time the material volume change of the landslides zone increasingly becomes the dominant control on the basin.

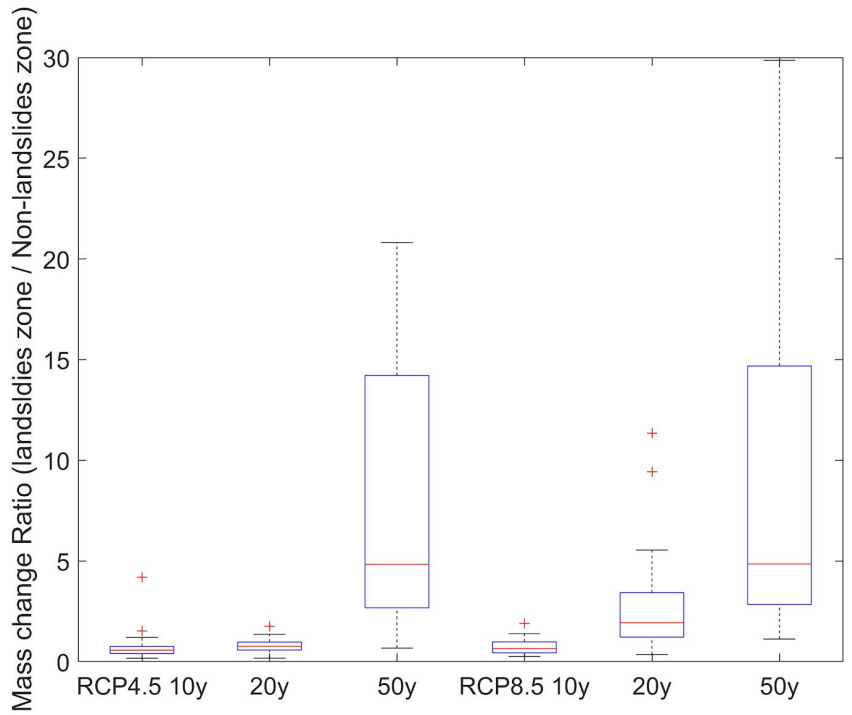

Fig. 13 The ratio between the mass volume change between the landslides zone and the non-landslides zone

\section{Discussion}

Due to the high uncertainty in climate change scenarios, we build a rainfall predicted model to provide the most robust and effective representative future climate change scenarios at local scale. The predicted model [34] have the advantage of being few in number as well as having a clear description of the seasonal variation of the climate signals and allowing easy interpretation of the implications of future changes. Since the predicted model is stochastic, 50 repeat data sets were generated in each temporal period. Compared with other researcher's study, the extreme value (50-year return period events) in the future in the southwest China will be increased both under the RCP4.5 and the RCP8.5 emission scenario, and the increase tendency are bigger under the RCP8.5 scenario [36]. In this study, the predicted rainfall results also support this conclusion, the possibility of the extreme rainfall (50-year return period events $(142 \mathrm{~mm})$ ) increased both under the RCP4.5 and the RCP8.5 emission scenarios, and very extreme rainfall (>>142mm) is more easily occurs under the RCP8.5 emission scenario (Fig. 16). 

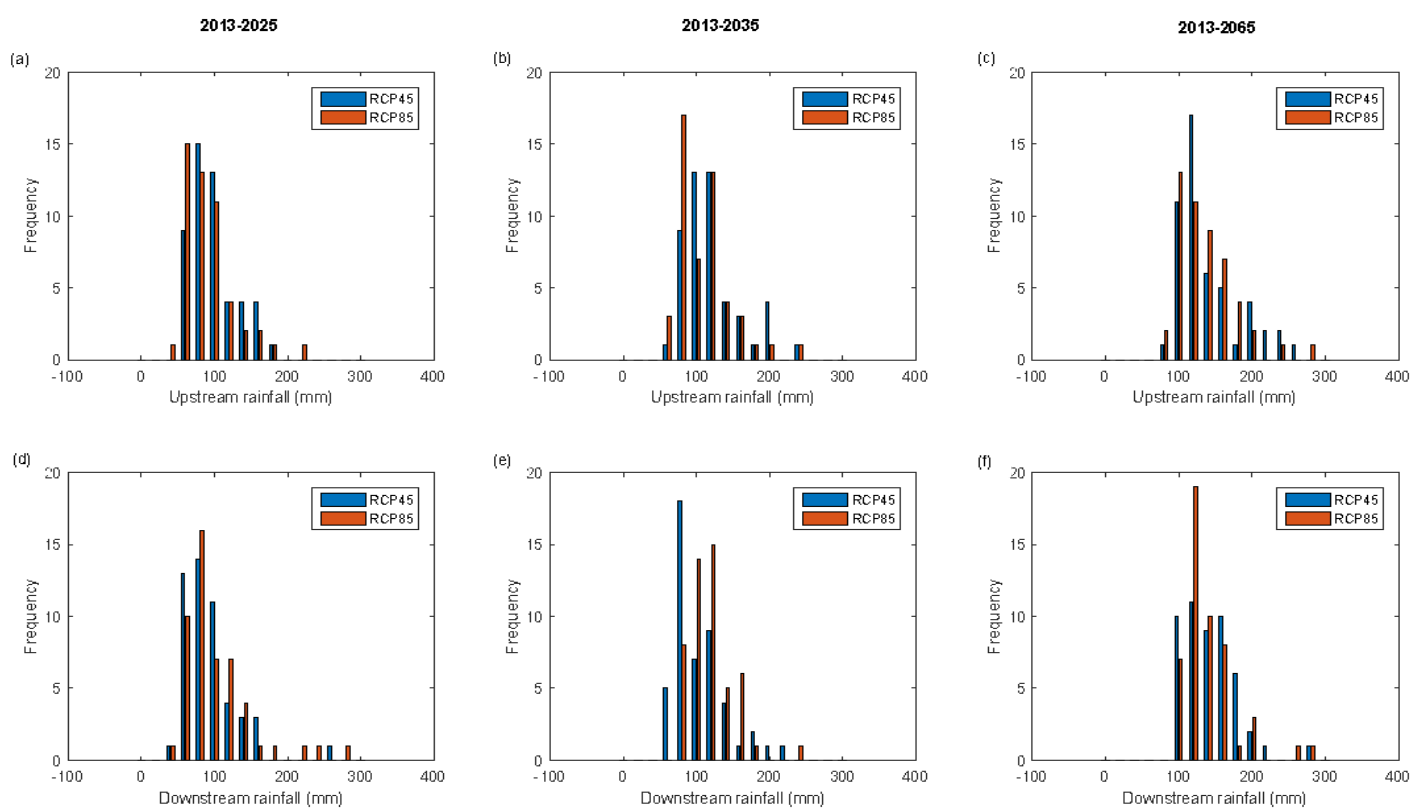

Fig. 16 The frequency of the extreme rainfall in the upstream and downstream area $((a)(d)$ are the results in 2013-2025; (b)(d) are the results in 2013-2035; (c)(f) are the results in 2013-2065.)

In our previous study [5], which continuously detected the topographic changes of the basin, the results showed that the materials and deposits mainly accumulated on upper-middle portions of mountain slopes and gullies after the earthquake, and the normal rainfall continued to erode the high mountain and accumulated the loose materials on upper-middle portions of mountain slopes and gullies. Under the rainfall, especially the high rainfall effects, readily induced debris flows and swept the loose materials downward, a large volume of loose materials filled the river channels and elevated riverbeds. This study provided further thought on future long-term (50y) topographic evolution, particularly the simulated erosion and deposition characteristics of at both basin scale and specific locations.

The high rainfall caused great erosion and deposition process to the basin, the whole volume of the basin fluctuated obviously [5], after a long time landscape evolution process, the sediment yield tends to be stable. From the prior study, the whole volume change of the basin is $4.87^{\star} 10^{\wedge} 8 \mathrm{~m}^{3}$ (derived from the DEM data of the spatial resolution $10 \mathrm{~m}$ ) [5], in this study, by the time when the geomorphology of the basin becomes stable, the yearly sediment yield keeps at a level of average rate $1^{\star} 10^{\wedge} 4 \mathrm{~m}^{3}$ (with spatial resolution $20 \mathrm{~m}$ ), it takes 10 thousands of years before the volume balance of the basin returned to the pre-earthquake level, much longer than the return period of the earthquake 2000-3000y [37, 38].

For sediment yield, the total sediment yield under the high emission scenario is lower than the results under the low emission scenario, which showed an opposite result compared with the work done in [39], general increase in total sediment yield with higher 
emissions scenarios. This result infers that when applying the RCMs at local scale, the effects caused by the high and low emission scenarios need to be analyzed on a case-by-case basis.

We also found that the geomorphology of the basin becomes stable after 20 years landscape evolution process (-2035), the results was supported by the study of other researchers [40-42], they believe that the active stage of the earthquake areas will be last for decades ( 20y). But how long the stable period last still need further debate.

\section{Conclusions}

This paper chooses one earthquake-stricken area as an example to analyze the basin response to the future climate change. Since the extreme rainfall in the NEX-GDDP dataset is significantly underestimated at our basin, we firstly do the future extreme rainfall prediction and then analyze the landscape evolution variation under future climate change with the CAESAR-Lisflood model. Considering the effects caused by the different temporal lines and emission scenarios, the following conclusions are drawn from the results of the study:

- The earthquake-stricken area still experience rapid and gradual changes in the geological and geomorphological environment. Under rainfall effects, loose materials triggered by the earthquake and landslides mainly accumulated in the river channels and floodplains and moves to the outlet over time which upper the river-bed, while mountain slopes and gullies showed persistent erosion tendency.

- By analyzing the landscape evolution of earthquake-stricken area in response to future climate change, it is clear that the mass balance of the lower basin area changed from deposition to erosion over time compared with the mass volume in 2013. 20 years are needed before the dramatic material transport and geomorphic changes of the basin been stable after 2013 , and the yearly sediment yield rate decreased over time until nearly 2035 with an yearly average rate $1^{*} 10^{\wedge} 4 \mathrm{~m}^{3}$. While for the whole basin mass balance, it still needs 10 thousands of years before the whole basin sediment returned back to the pre-earthquake level.

- The extreme rainfalls have greater effects on the areas with more landslides, due to the more fragile geological and geomorphic environment, such as more accumulated loose materials and less vegetation coverage. Thus, the materials migration of the post-earthquake mountainous areas with more landslides becomes the dominant control on topographic variation of the earthquake-stricken area, which will form a higher risk of geological disasters and mountain flooding.

- Cumulative sediment yields are not only determined by extreme rainfall but also the cumulative rainfall, extreme rainfall caused dramatic changes of the geographic environment and the sediment yield while cumulative rainfall continually effects the landscape evolution. 


\section{Acknowledgements}

This research was supported by the National Natural Science Foundation of China under grant numbers 41671503 , and by the University of Hulls CSC studentship scheme. CAESAR-Lisflood is freely available under a GNU license from https://sourceforge.net/projects/caesar-lisflood/

\section{References}

1. Cui, P., et al., The Wenchuan Earthquake (May 12, 2008), Sichuan Province, China, and resulting geohazards. Natural Hazards, 2011. 56(1): p. 19-36.

2. Yang, W.T., et al., Analysis of changes in post-seismic landslide distribution and its effect on building reconstruction. Natural Hazards \& Earth System Science, 2015. 15(4): p. 817-825.

3. Tang, C., et al., Landslides induced by the Wenchuan earthquake and the subsequent strong rainfall event: A case study in the Beichuan area of China. Engineering Geology, 2011. 122(1-2): p. 22-33.

4. Zhang, Y.S., et al., The evolution process of Wenchuan earthquake-landslide-debris flow geohazard chain. Geological Bulletin of China, 2013. 32(12): p. 1900-1910.

5. $\mathrm{Li}$, C., et al., Topographic changes and their driving factors after 2008 Wenchuan earthquake. Geomorphology, 2018. 311: p. 27-36.

6. Tang, C., et al., Analysing post-earthquake mass movement volume dynamics with multi-source DEMs. Engineering Geology, 2019. 248: p. 89-101.

7. $\mathrm{Li}, \mathrm{C}$., M. Wang, and K. Liu, A decadal evolution of landslides and debris flows after the Wenchuan earthquake. Geomorphology, 2018. 323: p. 1-12.

8. Tang, C., Z. Jiang, and W. Li. Seismic Landslide Evolution and Debris Flow Development: A Case Study in the Hongchun Catchment, Wenchuan Area of China. in Engineering Geology for Society and Territory - Volume 2. 2015. Cham: Springer International Publishing.

9. Xie, J., et al., Modeling sediment movement and channel response to rainfall variability after a major earthquake. Geomorphology, 2018. 320: p. 18-32.

10. Coulthard, T.J., et al., Integrating the LISFLOOD-FP 2D hydrodynamic model with the CAESAR model: implications for modelling landscape evolution. Earth Surface Processes \& Landforms, 2013. 38(15): p. 1897-1906.

11. Bates, P.D., M.S. Horritt, and T.J. Fewtrell, A simple inertial formulation of the shallow water equations for efficient two-dimensional flood inundation modelling. Journal of Hydrology, 2010. 387(1): p. 33-45.

12. Coulthard, T.J., M.G. Macklin, and M.J. Kirkby, A cellular model of Holocene upland river basin and alluvial fan evolution. Earth Surface Processes and Landforms, 2002. 27(3): p. 269-288.

13. Beven, K.J. and M.J. Kirkby, A physically based, variable contributing area model of basin hydrology / Un modèle à base physique de zone d'appel variable de l'hydrologie du bassin versant. Hydrological Sciences Bulletin, 1979. 24(1): p. 43-69.

14. Wiel, M.J.V.D., et al., Embedding reach-scale fluvial dynamics within the CAESAR cellular automaton landscape evolution model. Geomorphology, 2007. 90(3): p. 283-301.

15. Hancock, et al., An evaluation of landscape evolution models to simulate decadal and centennial scale soil erosion in grassland catchments. Journal of Hydrology, 2011. 398(3): p. 171-183.

16. Pelletier, J.D., Persistent drainage migration in a numerical landscape evolution model. Geophysical Research Letters, 2004. 31(20): p. 379-398.

17. Coulthard, T.J. and M.J.V.D. Wiel, A cellular model of river meandering. Earth Surface Processes \& Landforms, 2010. 31(1): p. 123-132.

18. Shennan, I., et al., Integration of shelf evolution and river basin models to simulate Holocene sediment dynamics of the Humber Estuary during periods of sea-level change and variations in catchment sediment supply. Science of the Total 
Environment, 2003. s 314-316: p. 737-754.

19. Skinner, C.J., et al., Global sensitivity analysis of parameter uncertainty in landscape evolution models. Geosci. Model Dev., 2018. 11(12): p. 4873-4888.

20. Coulthard, T.J., G.R. Hancock, and J.B.C. Lowry, Modelling soil erosion with a downscaled landscape evolution model. Earth Surface Processes and Landforms, 2012. 37(10): p. 1046-1055.

21. Hancock, G.R., et al., Hillslope and point based soil erosion - an evaluation of a Landscape Evolution Model. Earth Surface Processes and Landforms, 2019. 44(5): p. 1163-1177.

22. Bao, Y. and X. Wen, Projection of China's near- and long-term climate in a new high-resolution daily downscaled dataset NEX-GDDP. Journal of Meteorological Research, 2017. 31(1): p. 236-249.

23. Wang, G., et al., Variation Trend of RCP-based Climatic Scenarios for Yellow River Basin. Journal of China Hydrology, 2014.

24. Wang, R., et al., Multi-Model Projections of Climate Change in Different RCP Scenarios in an Arid Inland Region, Northwest China. Vol. 11. 2019. 347.

25. Luo, Z.W., Application of casting blast to emergency treatment of risk-elimination of Maanshi landslide dam. Water Resources and Hydropower Engineering, 2008. 39(8): p. 31-32.

26. Wang, M., et al., Incorporating Triggering and Environmental Factors in the Analysis of Earthquake-Induced Landslide Hazards. International Journal of Disaster Risk Science, 2014. 5(2): p. 125-135.

27. Thrasher, B., et al., Downscaled Climate Projections Suitable for Resource Management. Eos, Transactions American Geophysical Union, 2013. 94(37): p. 321-323.

28. Keefer, D.K., Landslides caused by earthquakes. Geological Society of America Bulletin, 1984. 95(4): p. 406.

29. Dai, F.C., C.F. Lee, and Y.Y. Ngai, Landslide risk assessment and management: an overview. Engineering Geology, 2002. 64(1): p. 65-87.

30. Crosta, G.B., Introduction to the special issue on rainfall-triggered landslides and debris flows. Engineering Geology, 2004. 73(3): p. 191-192.

31. Lin, G.W., et al., Effects of earthquake and cyclone sequencing on landsliding and fluvial sediment transfer in a mountain catchment. Earth Surface Processes \& Landforms, 2008. 33(9): p. 1354-1373.

32. Meunier, P., N. Hovius, and J.A. Haines, Topographic site effects and the location of earthquake induced landslides. Earth \& Planetary Science Letters, 2008. 275(3): p. 221-232.

33. Smith, S.G. and K.W. Wegmann, Precipitation, landsliding, and erosion across the Olympic Mountains, Washington State, USA. Geomorphology, 2018. 300: p. 141-150.

34. Ntegeka, V., et al., Developing tailored climate change scenarios for hydrological impact assessments. Journal of Hydrology, 2014. 508(2): p. 307-321.

35. Lee, T. and C. Jeong, Nonparametric statistical temporal downscaling of daily precipitation to hourly precipitation and implications for climate change scenarios. Journal of Hydrology, 2014. 510: p. 182-196.

36. Chen, H.-P., J.-Q. Sun, and H.-X. Li, Future changes in precipitation extremes over China using the NEX-GDDP high-resolution daily downscaled data-set. Atmospheric and Oceanic Science Letters, 2017. 10(6): p. 403-410.

37. Ouimet, W.B., Landslides associated with the May 12, 2008 Wenchuan earthquake: Implications for the erosion and tectonic evolution of the Longmen Shan. Tectonophysics, 2010. 491(1): p. 244-252.

38. Liu, F., J. Li, and S. Yang, Landslide erosion associated with the Wenchuan earthquake in the Minjiang River watershed: Implication for landscape evolution of the Longmen Shan, eastern Tibetan Plateau. Natural Hazards, 2015. 76(3): p. 1911-1926.

39. Coulthard, T.J., et al., Using the UKCPO9 probabilistic scenarios to model the amplified impact of climate change on drainage basin sediment yield. Hydrol. Earth Syst. Sci., 2012. 16(11): p. 4401-4416.

40. Huang, R. and W. Li, Post-earthquake landsliding and long-term impacts in the Wenchuan earthquake area, China. Engineering Geology, 2014. 182: p. 111-120.

41. Huang, R., After effect of geohazards induced by the Wenchuan Earthquake. Journal 
of Engineering Geology, 2011. 19(2): p. 145-151.

42. Zhang, S. and L.M. Zhang, Impact of the 2008 Wenchuan earthquake in China on subsequent long-term debris flow activities in the epicentral area. Geomorphology, 2017. 276: p. 86-103. 